\title{
炭化カルシウムの水蒸気との反応性に与える結晶状態の効果 $†$
}

\author{
（昭 和 36 年 1 月 16 日 受 理）
}

田川 博 章・藤 森 寛 治*

\begin{abstract}
炭化カルシウムと水蒸気とが反応する場合に，炭化カルシウムの結晶状態と反応性との間にいかなる関係があるかを明 らかにするために，X線回折法と熱天秤を使ってこの反応を調べた。

炭化カルシウムは室温に括いて 3 種の結晶型を持ち，いずれす正方晶系に属している。高純度の立方体形に結晶した炭 化カルシウムは [100], [110], [111] 方向に辟開しやすい。高温の結晶型 $\left(\mathrm{CaC}_{2} \mathrm{~N}\right)$ から低温型に結晶転移が起るとき, くり返し双晶が現われるので， $\mathrm{CaC}_{2}$ I では [100] については (100) と (001)，[110］では (110) と（101）が観察さ れる。これらの各結晶面の水蒸気との反応性は $(100)>(001)>(101)>(111)$ の順に小さくなる。また各結晶面から現わ れる水酸化カルシウムの結晶面は任意のものではなく，[100] からは (011), [110] からは (012), [111] では (001) が それぞれ認められた。

炭化カルシウムと水蒸気の反応は

$$
x^{2}=2 k^{\prime}\left(t-t_{0}\right)
$$

で表わされるので, 水酸化カルシウムの生成速度は生成層の厚さの逆数に比例するものと考えられる。ここで $x$ は生成層 の厚さ, $k^{\prime}$ は速度定数, $t$ は時間。室温, 水蒸気圧 $15 \mathrm{mmHg}$ での $k^{\prime}$ の値は [100], [110], [111] の各切断面につい

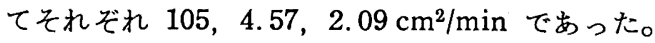

市販用炭化カルシウムは高純度のものと結晶状態が異なり, すべて $1 \mathrm{~mm}$ 以下の結晶粒の集合体からできている。水 蒸気との反応に拈いては高純度のものと同じょ５に, 反応速度は生成した水酸化カルシウムの層の厚さの逆数に比例す る。その速度は概していうと結晶粒の大きいるのが大きい。高純度のものにくらべてみると [100］と［110］切断面の間 の值になる。
\end{abstract}

\section{1 ま えがき}

炭化カルシウムの結晶状態は不純物の混在, 冷却の方法にいち じるしく支配される。炭化カルシウムは高温では $\mathrm{N}$ 型と呼ばれ， 面心立方格子をつくっているが， $450^{\circ} \mathrm{C}$ の転移点で任意の方向を とっていた $\mathrm{C}_{2}$ イオンが $c$ 軸方向に配列する傾向を持っているの で， $c$ 軸が延び， $a$ 軸が短かくなって，対称性の低い正方格子に 変わる11。この転移のとき外形をそれほど変えることなく，対称 性の低い結晶型に移るので，くり返えし双晶が現われる。特に高 純度の炭化カルシウムでは発達した双晶を観察することができ る。結晶の形態は炭化カルシウムに含まれている不純物, 特にイ オウイオンの影響を受ける2)。イオウイオンは $\mathrm{C}_{2}$ イオンの位置 に入り込み, $\mathrm{CaC}_{2}$ I 型を安定化させる ${ }^{3)}$ ともに柱状の形をと り，イオウイオンが少ない場合には $\mathrm{CaC}_{2} \mathrm{I}$, II, III が同時に現 われて立方体の形をとるよ5になる。炭化カルシウムは䢃開する 性質があり，䢃開面は（100）と（001）を含むか，(110）と（101） とを含むか，あるいは（111）からできている4。

純度がそれほど高くない市販用品, 通称カーバイドは $\mathrm{CaC}_{2}$ $80 \%, \mathrm{CaO}$ が $15 \%$ 程度含まれているために，炭化カルシウム が粒状になり, 粒子間を酸化カルシウムが覆っている状態になっ ている。個々の炭化カルシウムの粒子は時に大さいものにのみ双 晶線を認めることができるが, 市販品自体には䢃開性はなく, 結 晶の形も一定しない。急冷されたことも結晶性の悪い原因の一つ であろろと思われる。

†本報を「炭化物の生成と性質に関する研究(第 3 報)」とす る. 前報（第 2 報）は工化 63，1690（1960）.

* 日本カーバィド工業株式会社魚津研究所 : 富山県围津市本 新.

1) M. A. Bredig, J. Phys. Chem. 46, 801 (1942).

2) H.H. Frank, M. A. Bredig, Kin-Hsing Kou, Z. anorg. allgem. Chem. 232, 75 (1937).

3) W. Borchert, M. Röder, ibid. 302, 253 (1960).

4）田川, 藤森, 工化 63, 1154 (1960).
炭化カルシウムと水蒸気との反応はこれらの結晶状態が関与す ることが考えられる。高純度で結晶の形状が立方体あるいは柱状 形では辟開面に特徵を持ち，格子面の違いが原子密度の違いを意 味するので，水蒸気との反応ではエピタキシーが問題になりら), 反応速度の違いが期待される。市販品では結晶の形態あるいは双 晶の状態よりも粒子の大きさが，反応速度を支配するように思わ れる。そこでこれら結晶状態の相違が水蒸気との反応にどんな意 味を持つのかということについて調べた。

\section{2 純度の高い炭化カルシウムと水蒸気との反応}

大型電気炉の操業をとめ, そのまま放冷しておくとき, 炉の中 央部分に結晶性のよい炭化カルシウムの大きな塊を得ることがで さる。この塊は䢃開性があり，立方体の䢃開面からは [100]，[110]， [111] の各切断面が容易に得られるので, それぞれの面を切り出 し, X線回折法によって水蒸気との反応の状況を調べ, 一方, こ れらの結晶面の水蒸気との反応速度を検討した。

\section{$2 \cdot 1$ 試 料}

高純度の炭化物の試料として立方体形と柱状形の 2 種を選ん だ。立方体の結晶は䢃開して絶えず立方体の形をつくる。[100], [110], [111] はそれぞれ䢃開面になるので, この面を切り出し, X線回折した結果は既に報告したように (100) と (001)，(110）と (101), (111) の各結晶面を持っている。柱状形の場合は (100) と （001）とを含む䢃開面を使った。立方体と柱状形の種類の化学分 析值についても既報しだ)。

いずれの面も流動パラフィンを滑剂としてカーボランダムの研 磨機を用いて磨いた。つぎにこの磨いた面を空気中に一定時間放 置したのち, 表面に流動パラフィンを塗り, X線回折用試料板に 油粘土で固定した。走査はブラッグ角 $2 \theta$ が $70^{\circ}$ から $15^{\circ}$ まで $1 \% \min$ の速さで行なった。

空気中の水蒸気との反応はX線回折を行なった試料と同じ切断

5) R. Gomer, C.S. Smith, "Structure and Properties of Solid Surfaces" p. 318 (1953) Univ. of Chicago Press. 
面を研磨したのち，表面に付着してい る流動パラフィンを拭い取り，ただち に直示天秤に載せて重量変化を時間と ともに調べた。

\section{$2 \cdot 2 \mathrm{X}$ 線回折法による結晶面の変 化の検討}

立方体形の炭化カルシウムの [100], [110], [111] の各切断面の空気中での 水蒸気との反応の状況を $\mathrm{X}$ 線回折によ って求めたものが図 1 の (1), (2), (3) である。

図1は立方体の一つの面であって, [100] 切断面になる。この面は $\mathrm{CaC}_{2}$ I 型では $(002)$ と (200), $\mathrm{CaC}_{2}$ II と III型は $(800)$ と (008) とが現われ， $\mathrm{CaC}_{2}$ II と吕の (800) は重なっている。 それ以外の回折面はここでは認められ ない。この研磨した面に流動パラフィ ンが塗られているが，これを拭い取っ て，所定の時間空気中に曝したのち， 再び流動パラフィンで表面を覆って $2 \theta$ が $70^{\circ}$ から低角側へ走査した結果 が図 1 の [20 min 後] の結果であり， 長い時間，少なくとも 1 時間以上空気 中に放置してから回折した結果が [完
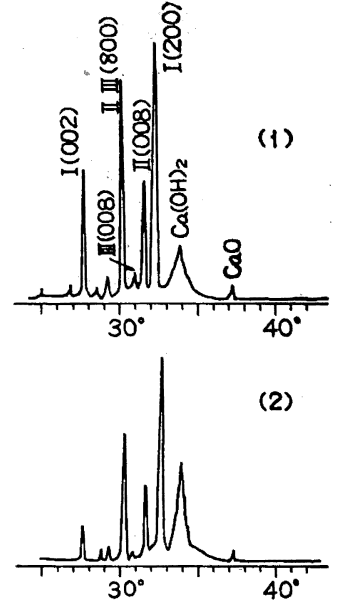

(3)

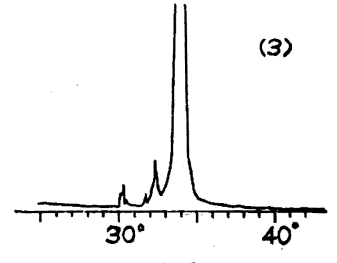

$2 \theta\left({ }^{\circ}\right)$

図 1 [100] 切断面の 変化

$\mathrm{Cu} K_{\alpha}(\mathrm{Ni}$ フィルター), $30 \mathrm{kV}-$ $15 \mathrm{~mA}, 16-1-4,1^{\circ}-1^{\circ}-0.1 \mathrm{~mm}$, $1 \% \mathrm{~min}$

(1): 反忘前, (2) $: 20 \mathrm{~min}$ 後 (3)：完全風化 全風化] 図である。図 1 の（1）と（2）とをくらべて, $\mathrm{CaC}_{2}$
I は (200) よりも (002) が早く反応し, $\mathrm{CaC}_{2} \mathrm{II}$ と III の (800) はこれらの間に属する。炭化カルシウムが水酸化カルシウムに変 化した場合の回折像は $2 \theta=34^{\circ}$ の (011) のみである。その他の 回折像はみられなかった。したがって特定の結晶面から生成する 水酸化カルシウムの結晶子は特定の結晶方向に成長することがわ かる。（3）はほぼ完全に風化したもので, わずかに $\mathrm{CaC}_{2} \mathrm{I}(200)$, $\mathrm{CaC}_{2}$ II, III の (800) のみ認めることがでさた。各結晶面の水蒸 気との反応の速さは

$$
\mathrm{I}(002)>\mathrm{II}+\mathrm{III}(800)>\mathrm{I}(200)
$$

この反応時の水蒸気圧は $15 \mathrm{mmHg}$, 気温は $25^{\circ} \mathrm{C}$ であった。

立方体の一つの面に $45^{\circ}$ で切った面，すなわち，[110] 切断面 と水蒸気と反応してからの面の変化のX線回折像が図 2 である。 この回折面は $\mathrm{CaC}_{2} \mathrm{I}$ は (202) と（220）を含むが, $\mathrm{CaC}_{2}$ II と IIIは報告されている面指数 ${ }^{3}$ と図 2 とが一致しないので，指数づ けしなかった。図2の（2）と（3）を（1）とくらべてみると $\mathrm{CaC}_{2}$ I の (220) は (202) の変化よりも遅い。水酸化カルシウ ムの結晶面は (012) のみで， [100］切断面のときに現われた (011) は全く存在しない。

[111] 切断面では $\mathrm{CaC}_{2}$ I の (111) と $\mathrm{CaC}_{2}$ II と III の (444) がX線回折の結果現われる。これを図 3 に示した。そのほか高次 の回折線 $\mathrm{CaC}_{2}$ I (222) を認めるほか, 他の回折線はみられなか った。この面が空気中の水蒸気と反応すると, その近傍に水酸化 カルシウムの回折像が現われる。この面は（001）であった。

かよ5に炭化カルシウムの各結晶面とそれから生ずる水酸化カ ルシウムの結晶面とは密接な関係のあることが見出された。その 対応性は
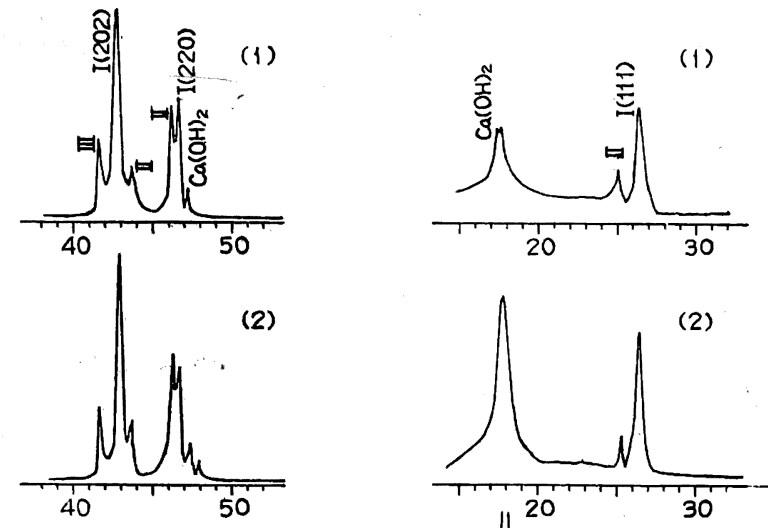

(3)

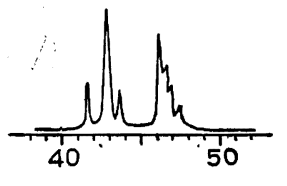

(4)

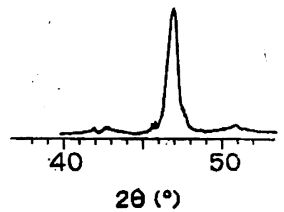

図 2 [110] 切断面の変化 $\mathrm{Cu} K_{\alpha}(\mathrm{Ni} フ$ イルター $), 30 \mathrm{kV}-15 \mathrm{~mA}$, $8-1-4,1^{\circ}-1^{\circ}-0.1 \mathrm{~mm}, 1^{\circ} / \mathrm{min}$ (1): 反応前, (2) $: 20 \mathrm{~min}$ 後 (3)：40 min 後，（4）：完全風化

$\begin{aligned} \mathrm{CaC}_{2} \mathrm{I} & (001),(100): \\ & (101),(110): \\ & (111):\end{aligned}$

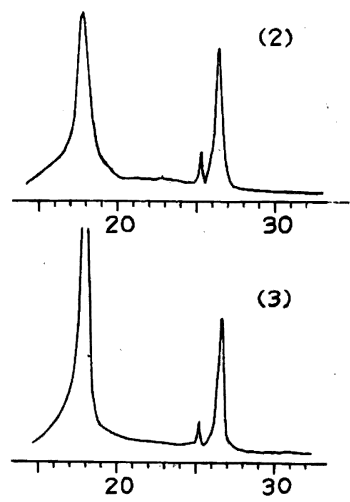

(4)

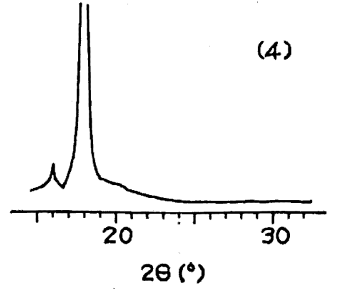

図 3 [111] 切断面の変化 $\mathrm{Cu} K_{\alpha}(\mathrm{Ni}$ フィルター), $30 \mathrm{kV}-15 \mathrm{~mA}$, $4-1-4,1^{\circ}-1^{\circ}-0.1 \mathrm{~mm}, 1^{\circ} / \mathrm{min}$ (1) : 反応前, (2): $20 \mathrm{~min}$ 後 (3)：40 min 後, (4): 完全風化

$\mathrm{Ca}(\mathrm{OH})_{2} \quad(011)$

となる。また各結晶面の水蒸気との反応のし易さは図 1 3 の回 折線の強度の堿少から

$$
(001)>(100)>(101)>(110)>(111)
$$

となる。これらの現象はエピタキシーで説明されようら)。な打炭 化カルシウム I 型の結晶面の原子密度は

$$
(001)>(100)>(101)>(110)
$$

の順に小さくなる。(111) はカルシウムイオンあるいは炭素イオ ンが層構造になるので, 他の結晶面と性質が異なる。水酸化カル シウムの結晶面の原子密度は (011)>(012) である。

\section{$2 \cdot 3$ 結晶面と水蒸気との反応速度の関係}

実験に使った試料はX線回折を行なった試料と同じ切断面を研 磨したのち，表面に付着している流動パラフィンを取り去り， 1 面を残して他の面をバルサムで覆い，一つの面を空気中に放置し た場合の重量変化を調べた。その結果を図 4 亿示した。それぞれ の䢃開面は水蒸気との反応の挙動が異なり，時間とともに重量増 加の最もいちじるしいものは [100] 切断面, すなわち， $\mathrm{CaC}_{2} \mathrm{I}$ では (001) と (100), $\mathrm{CaC}_{2}$ II と III では $(008)$ と (800) の格 子面を含む面である。柱状形の辟開面の場合には $\mathrm{CaC}_{2} \mathrm{I}$ のみか らできていて，その格子面は（001）と（100）であることが立方 体形と異なるところである。重量增加の時間に対する割合は立方 体形のそれに較べると小さい。このことは $\mathrm{CaC}_{2} \mathrm{I}$ よりも $\mathrm{CaC}_{2}$ II と IIIの水蒸気との反応速度が大きいことを意味する。立方体形 


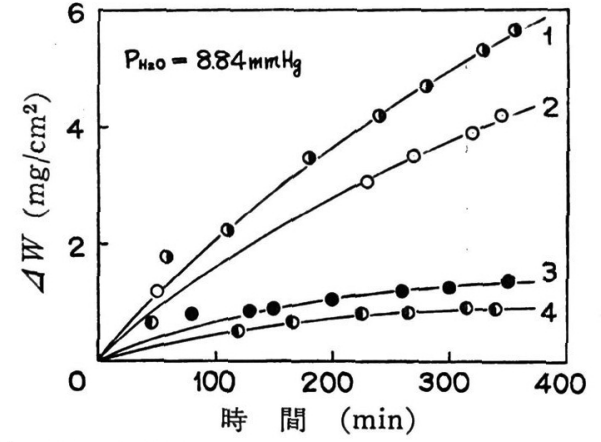

図 4 高純度岑化カルシウムの辟開面と水蒸気反応性 $\left(P_{\mathrm{H}_{2} \mathrm{O}}=8.84 \mathrm{mmHg}\right)$

1. 立方体形 $[100]$ 切断面 2. 柱状形等開面 $(100)+(001)$

3. 立方体形 [110] 切断面 4. 立方体形 [111] 切断面

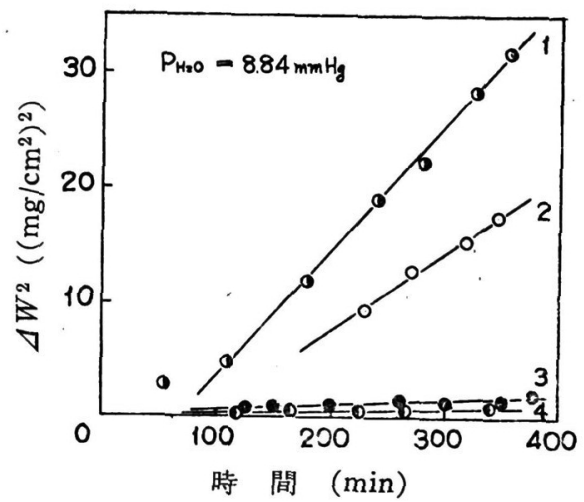

図 5 高純度炭化カルシウムと水蒸気の反応に扩ける時間と

重量増加の平方との関係 $\left(P_{\mathrm{H}_{2} \mathrm{O}}=8.84 \mathrm{mmHg}\right)$

1. 立方体形 [100] 切断面 2. 椾状形镜開面 $(100)+(001)$

3. 立方体形 [110] 切断面 4. 立方体形 [111] 切断面

の [110] と [111] で切断した面は [100] の切断面に較べるとは るかに小さな值になっている。[111] が最も小さい。このことは X線回折の結果と非常によい一致を示している。いずれの切断面 の変化でも，その重量増加曲線は直線ではなく抛物線的である。 この関係を明らかにするために重量增加 $\Delta W$ の平方と時間との 関係を図示したものが図 5 である。

図 4 では，いずれる抛物線状の曲線を示すが，時間 $t$ 之重量増 加の平方 $\Delta W^{2}$ との関係はいずれも直線を示す。 $t-\Delta W^{2}$ の直 線はすべて原点を通らず，ある時間のところで横軸を切る。この 重量増加の平方と時間とが直線関係を満足することは, 反応界面 が一定であることから，水蒸気と反応した水酸化カルシウムの層 が水蒸気の拡散抵抗になることを意味しているように思われる。 炭化カルシウムの反応界面の面積を $S\left[\mathrm{~cm}^{2}\right]$, 反応した炭化カル シウムの層の深さ $x[\mathrm{~cm}]$, 密度 $\rho\left[\mathrm{g} / \mathrm{cm}^{3}\right]$, 炭化カルシウムか ら水酸化カルシウムへ变わったときの重量增加 $\Delta W[\mathrm{~g}]$, 純度 pとすれば

$$
\rho \cdot S \cdot x \cdot p 74 / 64=\Delta W
$$

の関係が成り立つ。純度 $90 \%$ の炭化カルシウムの密度は $2.2 \mathrm{~g} /$ $\mathrm{cm}^{3}$ であるから

$$
x=0.437 \triangle W
$$

となる。一方, 反応時間 $t$ と重量增加の平方 $\Delta W^{2}$ との間には

(2) の関係式が成り立つ。

$$
\Delta W^{2}=2 k\left(t-t_{0}\right)
$$

ここで $t_{0}$ は $\Delta W^{2}-t$ 直線が時間軸を横切るときの值である。

\begin{tabular}{|c|c|c|}
\hline 結晶面 速度定数 & {$\left[\left(\mathrm{mg} / \mathrm{cm}^{2}\right)^{2} / \mathrm{min}\right]$} & {$\left[\begin{array}{c}k^{\prime} \\
{\left[\mathrm{cm}^{2} / \mathrm{min}\right]}\end{array}\right.$} \\
\hline 立方体形 [100] 切断面 & $5.55 \times 10^{-2}$ & $105 \times 10^{-10}$ \\
\hline 柱状等開面 $(100)+(001)$ & $3.43 "$ & $65.0 "$ \\
\hline 立方体形 [110］切断面 & $0.24 "$ & $4.57 \mathrm{II}$ \\
\hline 立方体形 [111] 切断面 & $0.11 "$ & 2.09 " \\
\hline
\end{tabular}
(2) 式の $k$ を図 5 の直線の勾配から求めた結果を表 1 に示した。
表 1 炭化カルシウムと水蒸気の反応の速度定数

同時に（2）式の重量増加量 $\Delta W$ の代わりに反応した炭化カル シウムの層の厚さ $x$ で表わした（3）式の $k^{\prime}$ も垪記した。

$$
x^{2}=2 k^{\prime}\left(t-t_{0}\right)
$$

表 1 で明らかなように，立方体形と柱状形の（100）と（001） とを含む結晶面は他の立方体の [110] と [111] との切断面にくら べると水蒸気に対する親和性が非常によい。立方体形の [100] 切 断面は炭化カルシウムのＩ型のほかにII型, 回型を含み, 柱状形 の場合には I 型の (100) と （001）のみを含むために両 者の水蒸気との反応の速度 が異なったものであって, これらの結果からは I 型に くらべてII型, III型の結晶 面が水蒸気に対する反応性 が大きいよ5に思われる。

\section{3 市販用炭化カルシウ 么の水蒸気 との反応}

工業的に多量に生産され ている炭化カルシウムは $2000^{\circ} \mathrm{C}$ 付近ないしはそ れよりも高い温度で電気炉 から液状で取り出され, 空 気中で放冷される。この冷 却過程で結晶成長が起り, インゴットの表㟄と内部の 結晶粒の大きさの違いが現 われる。これらの結晶状態 についてはすでに述べた が4), 不純物の介在する孷 化カルシウムの水蒸気との 反応の挙動についてここで 調べた。

炭化カルシウムが水蒸気 と反応する場合の変化を明 らかにするために，炭化カ ルシウムの表面をエメリー を使って研磨したのち，反 射顕微鏡を使って, 表面が 空気中に放置された状態に ついて観察した。図6は変 化した炭化カルシウムの顕 微鏡写真である。(1)は研 磨したのち 1〜2 分を経過 したもので, 炭化カルシウ ムの表面が局部的に白色の 水酸化カルシウムに変る。

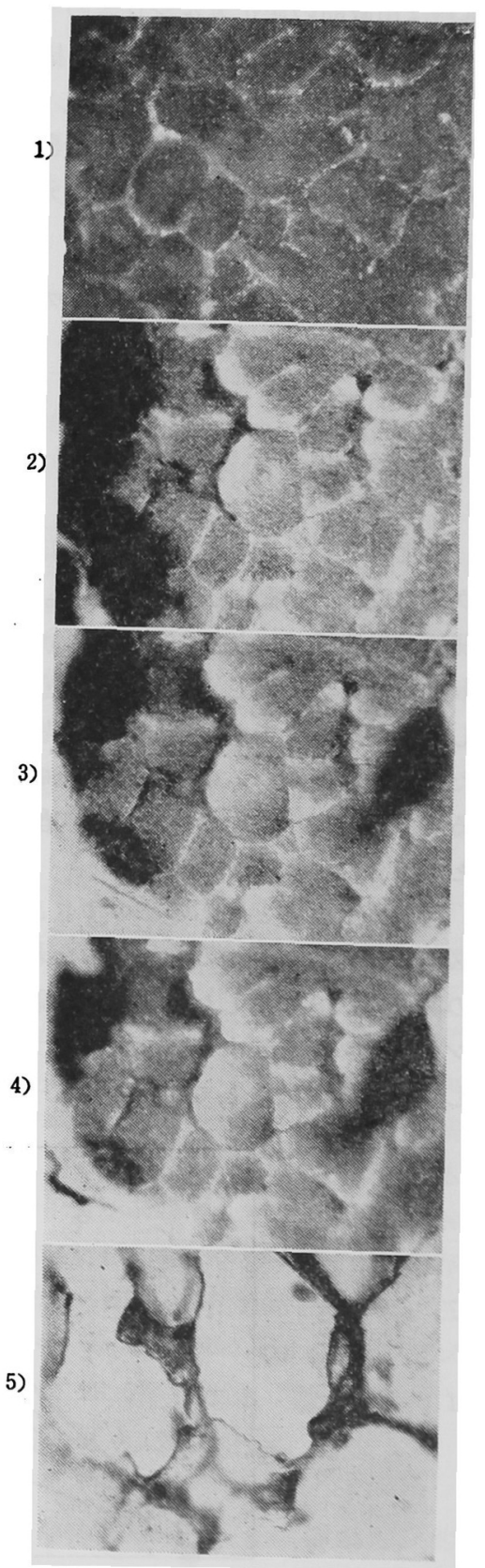

図 6 炭化カルシウムの水蒸気, 水 との反応 $(30 \times 5)$ のみ $50 \times)$

1) 研磨後 1 2 $\mathrm{min}$ 空気中に放羁

2) $4 \mathrm{~min}$ 後 3) $10 \mathrm{~min}$ 後

4) $15 \mathrm{~min}$ 後

5）水と反応した炭化カルシウム 
粒間に存在する酸化カルシウムは何らの変化も認められない。 （2）は4 分後のものであって水酸化カルシウムの層が全面に拡 がるが, 酸化カルシウムの部分は変化しない。炭化カルシウムの みが反応し表面が隆起する。15 分後でも酸化カルシウムの変化 は見られなかった。（5）は水々瞬間的に反応した炭化カルシウ ムの表面を示したものであって, 生成した水酸化カルシウムがガ ラス状の結晶になり，表面に付着する。一方界面に存在する酸化 カルシウムは変化しない。叔そらく酸化カルシウムは高温で析出 したために, 密な状態になり, 水と反応しにくかったのであろ 3。

高純度の炭化カルシウムと市販用品の結晶性の違いが, 水蒸気 との反応性に与える影響を明らかにするために炭化カルシウムを 空気中に放置したときの水蒸気との反応の速さについて調べた。 試料は市販品の炭化カルシウムのインゴットから採取した。採取 位置の異なる試料を薄片にして，顕微鏡で粒子の大きさを測定し た。一つの面をエメリーで研磨して平滑にし， $1 \sim 3 \mathrm{~cm}^{2}$ の面積 を残して他の部分をパラフィンで覆った。これを空気中に放置し て重量变化を調べた。試料の化学分析値の代表的例を表 2 に示し た。

$\begin{array}{lllr}\text { 表 } 2 & \text { 市肘用炭化カルシウムの化学分析値 }(\%) \\ \mathrm{C} & 0.08 & \mathrm{CaC}_{2} & 81.56 \\ \mathrm{SiO} & 1.16 & \mathrm{CaO} & 14.58 \\ \mathrm{Fe}_{2} \mathrm{Si} & 0.81 & \mathrm{CaS} & 0.69 \\ \mathrm{Fe}_{2} \mathrm{O}_{3} & 0.16 & \mathrm{CaCO}_{3} & 0.13 \\ \mathrm{Al}_{2} \mathrm{O}_{3} & 1.13 & \mathrm{Ca}_{3} \mathrm{P}_{2} & 0.03 \\ \mathrm{MgO} & 0.09 & \text { 全空菜 } & 0.12\end{array}$

炭化カルシウムの水蒸気との反応の挙動は高純度の炭化カルシ ウムの反応の挙動によく似ている。すなわち, 時間と重量增加の 関係が抛物線状になる。そこで高純度の炭化カルシウムについて 取扱った方法と同じょうに時間と重量增加の平方との関係を図示 したものが図 7 である。いずれの場合も直線状であって, 生成し た水酸化カルシウムの層が水蒸気の拡散抵抗になることを意味す る。この図では粒子の大きさと勾配との関係をはっきり読取るこ とができない。

粒子の大きさと反応のしやすさとの関係を明らかにするために 図 7 で得られた直線の勾配, すなわち，(2) 式の $k$ 之粒子径と の関係を図 8 に示した。粒子径は顕微鏡写真から読取ったが，サ ンプリングの数が少ないので, 最大值と最小值の平均を粒子径と した。図8では概してい5と，粒子径が大きくなると速度定数 $k$

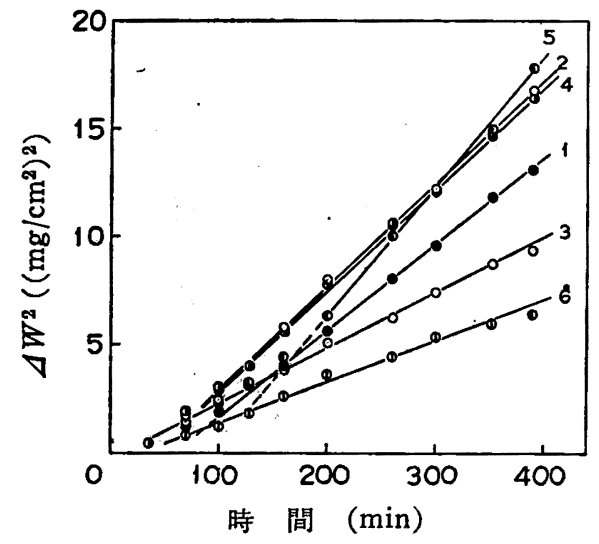

因 7 市販用炭化カルシウムと水蒸気との反応 粒子径 1: 90 120 $\mu, 2: 80 \sim 120 \mu, 3: 90 \sim 120 \mu$ $4: 80 \sim 110 \mu, 5: 120 \sim 140 \mu, 6: 100 \sim 140 \mu$

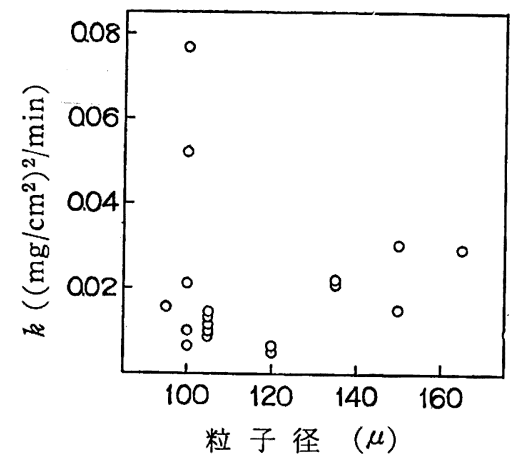

図 8 市肘用炭化カルシウムの粒子径と速度定数との関係

が大きくなることが指摘できる。これらの速度の大きさは高純度 の炭化カルシウムにくらべてみると, [100] 切断面と [110] 切断 面の間にあることが明らかである。

\section{4 考察}

高純度の炭化カルシウムが水蒸気と反応した場合に, 炭化カル シウムの結晶面と生成する水酸化カルシウムの結晶面との間には 密接な関係がある。炭化カルシウムI 型の結晶面と, それからで きる水酸化カルシウムの結晶面との対応を図 9 に示した。(001) と (100) はカルシウムイオンと炭素イオンとが面心状態酒配置し ているが，(101) と（110）はカルシウムイオンが層状にならぶ。 生成する水酸化カルシウムの結晶面は $\mathrm{CaC}_{2} \mathrm{I}$ の (001) と (100) とからは (011) が, (101) と（110）とからは.(012) ができるが, （011）はカルシウムイオンと水酸イオンが交互に層状に，(012） ではカルシウムイオン 1 層に対し.て水酸イオンが 2 層に交互にな らんで結晶面をつくる。(111) はカルシウムイオンのみの層, 炭 素イオンのみの層が交互に紙面方向に積み重なっているために他 の結晶面と挙動が異なっている。生成する水酸化カルシウムもカ ルシウムイオンと水酸イオンの層状が, 紙面に垂直な方面化延び ている。炭化カルシウムの (001), (100), (101), (110) の各結晶 面の原子密度の逆数はそれぞれ $17.1,18.6,25.2,26.3 \AA^{2} / \mathrm{CaC}_{2}$ となり，反応性は原子密度の減少の順に小さくなることが明らか

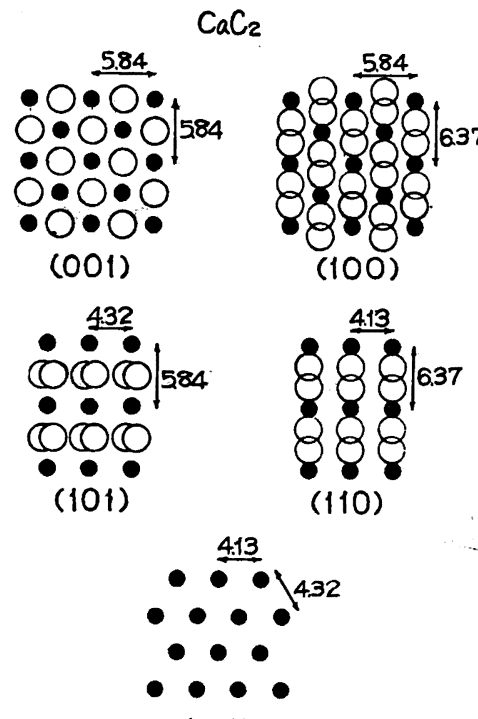

(111)
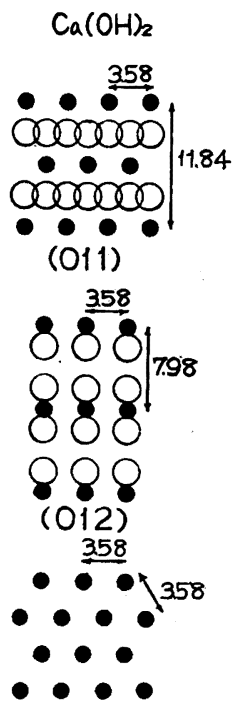

(001)
図 9 炭化カルシウム I 型の結晶面と水蒸気との反応によっ てできる水酸化カルシウムの結晶面との対応性 (単位 ̊̊) 黒丸は カルシウムイオン, 白丸は 炭菜あるいは水酸イオン 
である。

$\mathrm{CaC}_{2}$ I， II， III の混在した立方体形の [100] 切断面と， $\mathrm{CaC}_{2}$ I のみからできている柱状形の䢃開面 (100)+(001) との反応速度 をくらべてみると，前者が後者の約 2 倍の速度を持っている。炭 化カルシウムが高温で䆓素と反応してカルシウムシアナミドに変 化する速さは Frank らの)によると，型が最も大きく， II， I 型 の順に減少することが報告されている。炭化カルシウムが水蒸気 と反応して水酸化カルシウムが生成する場合には, 結晶面が反応 速度に大きな影響を与えたという事実から，扣そらく結晶型の違 いによる活性度の違いが現われ，それもI型よりも II, II 型が水 蒸気との反応速度が大きいと考兄られる。この理由についてはい まのところ明らかではない。

6) H.H. Frank, M. A. Bredig, G. Hoffmann; Z. anorg. allgem. Chem. 232, 61 (1937).
工業用につくられた炭化カルシウムは炭化カルシウムが大きな 結晶に成長せずに, $200 \mu$ 程度の粒状になっていて粒間には多く 酸化カルシウムが存在する。炭化カルシウムの純度が高ければ水 蒸気との反応の激しいことが考えられる。一般的に，粒子径の大 きい炭化カルシウムは純度が高いので, 粒子径の大きいものほど 水蒸気との反応速度の大きいことが期待されたが，一義的な関係 が得られなかった。このことは試料の結晶状態が採取位固に依存 するために，粒子径と純度とが必ずしす同一の関係になく，また 不純物の介在の状態も試料ごとに異なること，それに図 8 の粒子 径が粒子分布から求めた值というよりは, 最大值と最小値の平均 であるといったことが原因しているものと考えられる。

（昭和 35 年 4 月，日化第 13 年会講演）

終りに発表を許可された会社上司の方に厚く感謝します。

\title{
四塩化炭素およびクロロホルム中における三塩化ホウ素と酸了ミドとの反応生成物
}

\author{
（昭 和 36 年 6 月 14 日 受 理）
}

中 川雅 直*

\begin{abstract}
半導体用ヶイ素の原料であるバゲン化ケイ素中の微量ホウ素分と酸アミドとの反応を基礎的に検討するため, 四塩化 炭素拉よびクロロホルム中における三塩化ホウ素と酸アミドとの反応生成物について調べ，またその反応に及ぼす四塩化

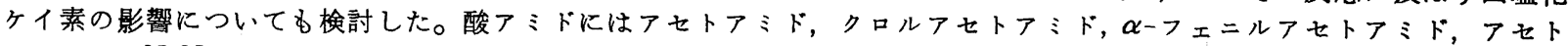
フニリド， N, N-ジフェニルアセトアミド执よびベンズフミドを用い，三塩化ホウ素は約 $1.2 \mathrm{~mol} / l$ 溶液とし，その $25 \mathrm{cc}$ をとってこれに当量の酸アミドを常温で反応させた。その結果，反応生成物は三塩化ホウ素と酸了ミドとの分子間化合物 と, それから塩化水素あるいは塩化ア七チルがとれてできた化合物との混合物であると考えられ，一般に幾分極性のある クロロホルム中に拈ける反応生成物は四塩化炭素中に特ける生成物よりる塩素が少ないるのができることがわかった。ま た三塩化ホウ素と四塩化ヶイ素が共存する場合にも，ほぼ同様のホウ素化合物ができることが知られた。
\end{abstract}

\section{1 緒言}

アセトアミドおよびアセトアニリドは低温で三塩化ホウ素と反

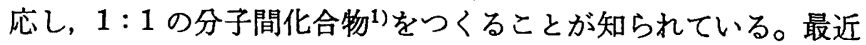

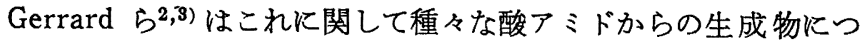
いて検討した。著者) は Gerrard らに先立って酸アミドが四塩化 ケイ素中の微量のホウ素分（三塩化ホウ素として存在すると考兄 られる）と反応して分子間化合物に近いものを生成し，それを口 過するか, あるいは四塩化ケイ素を蒸留することによってその中 の微量のホウ素分をある程度除き得ることを報告した。本研究は 四塩化ヶイ素中のホウ素分除去に関する基礎的研究として行なっ たあのであって，四塩化ケイ素怙よびトリクロルシランに対応す る分子構造をもつ溶媒として四塩化炭素およびクロロホルムを選 び，その中に溶解させた三塩化ホウ素と酸アミドを常温で反応さ せ，生成した沈殷，ならびに沈殷を分離した後の溶液中の生成物 の組成を調べた※1結果である。

* 東京工業試験所：東京都涉谷区本町.

1) W. Gerrard, M.F. Lappert, Chem. Rev. 58, 1081 (1958).

2) W. Gerrard, M.F. Lappert, J. W. Wallis, J. Chem. Soc. 1960, 2141.

3) W. Gerrard, M.F. Lappert, H.Pysozora, J. W. Wallis, ibid. 1960, 2144.

4) 中川, 工化 63,2115 (1960)

\section{2 実 験 方 法}

$2 \cdot 1$ 試 薬

酸アミドは次のようなものを用いた。すなわちアセトアミド $\left(\mathrm{AcNH}_{2}, \mathrm{~N} 21.8 \%\right) ，$ クルアセトアミド $\left(\mathrm{ClAcNH}_{2}, \mathrm{~N} 10.7\right.$

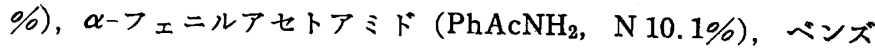
アミド $\left(\mathrm{PhCONH}_{2}, \mathrm{~N} 11.3 \%\right)$ などの第 1 級アミド，第 2 級ア ミドとしてアセトアニリド，第 3 級である $\mathrm{N}, \mathrm{N}-$ 济フェニルアセ トアミドなどである。これらの試薬は特級または 1 級品を十分精 製してから使用した。なおアミドの名称の後には本報で使用する 略号とともに精製品の窒素の分析值を示してある。四塩化炭素拉 よびクロロホルムは脱水, 精製したものをデシケーター中に保存 して使用し，四塩化ヶイ示は既報4) と同一の精製品を用いた。三 塩化ホウ素は American Potasch \& Chemical Corp. 製のボン ベ入りのものであってその純度は $99.5 \%$ である（遊離塩素 0.1 $\%$, Si $0.001 \%$, S $0.03 \%$ 以下, C $0.1 \%$ 以下)。

\section{$2 \cdot 2$ 反応および処理の方法}

三塩化ホウ素は四塩化炭素またはク口ロホルムに溶解し、約

※1 半導体用ケイ素の原料として用いるハロゲン化ヶイ素は $1 \mathrm{ppm} \sim 0.1 \mathrm{ppb}$ 程度のホウ素分を含有している。このよ 5 に非常に希薄な溶液中での反応生成物について調べるこ とは実際問題としてできないので，本研究では三塩化ホウ 素は約 $1.2 \mathrm{~N}$ 溶液として用いた。濃度の違いによる反応 生成物の組成その他の相違については別途に検討を要する。 